\title{
Values as Predictors of Attitudes toward Changes and Organizational Learning in Turkish Organizations
}

\author{
Ruth Alas, Halil Demirer, and Necdet Bilgin
}

\begin{abstract}
This empirical study in Turkish hotels contributes to our understanding of how work related values influence the readiness to change. Empirical research with 1267 indicates that work related values predict attitudes toward change and organizational learning. Guidelines for managers and a model are subsequently developed.
\end{abstract}

Index Terms-Organizational change, attitudes toward change, organizational learning, work-related values, Turkey.

\section{INTRODUCTION}

In order to survive in turbulent environment, organizations must change [1]. Still, there is high probability that when change efforts fail a crisis will occur [2]. Although the success of changes depends on several factors, the human factor is a critical resource in change management. Change must be implemented by employees - change recipients [3], moreover employees' supportive and creative behaviors have been considered as the success factors of change [4], [5]. Individuals in organizations vary in their readiness to accept change [6].

Organizations exist and operate within specialised institutional environments and could themselves be nested within and interdependent on larger encompassing systems [7]. Therefore this article will also apply institutional theory. Institutions are defined as systems composed of regulative, normative and cultural-cognitive elements that act to produce meaning, stability and order [5]. Therefore in current study institutional framework is included.

The aim of this paper is to study the connections between attitudes toward changes and organizational learning in Turkish organizations. In this paper the authors will first present the theoretical framework, followed by analyses of empirical data collected from Turkish organizations and finally, based on these empirical findings, implications for managers of Turkish hotels will be discussed and a model would be developed.

\section{THE THEORETICAL FRAMEWORK}

\section{A. Attitudes toward Changes}

There are people who plan changes and people that should implement changes, and also people who are affected by changes [6]. The smooth operation of organizational change and employees' attitudes toward that change is closely related [9]. Employee's readiness has been viewed as the core

Manuscript received May 9, 2013; revised July 19, 2013.

Ruth Alas is with Estonian Business School (e-mail: ruth.alas@ebs.ee). factor in determining work behaviors and organizational interactions [10]. The readiness factors act like a bridge between identifying what needs to happen and the activity of implementing the change [11]. Attitudes toward change are defined as "a person's cognitions about change, affective reactions to change, and behavioural tendency toward change [12]. Mullan and Gorman define openness towards change as support for and a positive effect on the potential consequences of the change [13].

In motivating individuals to support changes the first priority should be given to keep them in the organization. To do so, positive affective commitment of individuals to the organization should be attained which in turn result in the satisfaction at the workplace. Since, affective commitment is viewed as a good indicator of intention to stay or quit the organizations [14].

In the context of organizational change, attitudes to change - the benefits of the change and the competence of managers to implement these changes - become important [15]. In this article the authors focus on two readiness factors - employee attitudes and organizational learning - and impact of values on these factors.

\section{B. Organizational Learning}

Universal challenge of change is to learn how organizations and employees can change faster than changing business conditions to become more competitive [16]. Before people and companies can improve, they first must learn [17]. Senge defined learning organization as "an organization that is continually expanding its capacity to create its future" [18]. He argues that unless people change their thinking and interactions, the organization cannot change or learn on its own. Senge also claims that individual learning does not guarantee organizational learning. Organizational learning occurs through the sharing of experiences and dialogues among different employees in an organization [19].

Rosenstiel and Koch have defined organisational learning as a vital process by which organisations adapt to change in their social, political, or economic settings [20]. Tsang defines organizational learning in more detail as the learning which occurs in an organisation that produces real or potential change after a shift in the relationship between thought, organisational action and environmental response [21]. Emphasis on the connection between organisational learning and the environment in both definitions indicates that certain types of change in an environment may require a particular type of learning.

According to Senge the immediate change areas in promoting organizational learning can be identified as 
creating a shared vision, flexible systems and team dynamics [18]. Organizational learning emphasizes a socially constructed process, which proceeds through sharing interpretations of events and through reflection on these interpretations [22].

Attitude strength depends on the extent to which these attitudes are related to each person's own deeply held philosophical and political values and are of concern to the person's social group [23].

\section{Values}

Values have been defined as the principles or standards that people use, individually or collectively, to make judgments about what is important or valuable in their lives [24]. Values exist and are communicated through social connections and may vary in different cultures and different countries [25]. A small number of core ideas or cognitions present in every society about desirable end-state [26].

Values are the ideas and beliefs that influence and direct our choices and actions [27]. Adler defines values as "the cultural orientation of a society reflects the complex interaction of values, attitudes, and behaviors displayed by the members" [28, p. 17]. Work-related values or business values define the principles upon which everyone in the organization operates [29], these are the end states people desire and feel they ought to be able to realize through working [30].

\section{Institutional Development in Turkey}

In the 19th century the Ottoman Turks attempted to narrow the increasing gap that existed between Europe and the Ottoman Empire in technological and scientific developments. This was carried out by the "Tanzimat" reform movements, which proposed radical changes in the society [31], [32]. The Ottoman Turks obviously failed to transform their administrative structures towards capitalism, which would have enabled entrepreneurship to prosper [33].

During the 1930s the newly founded Republic pursued westernisation policies based on the principles of modernisation, secularism and nationalism [32]. Import substitution policies were pursued until the 1980s, which were a common aspect of the socialist economies of the era. Industrialisation was limited to the Marmara region, an area under government protection.

Subsequent to the 1980s, structural reforms in the liberalisation process were carried out, thus reducing state intervention. Integration into the conditions of the global economy was achieved by radical liberalisation policies in the domestic economy [34]. Integration into the European and common market was appreciated by industrialists [35].

Such changes on society level could be understood as institutional change, from both the structural and social perspective, embracing both structures and social values. During deinstitutionalisation and reinstitutionalisation the patterns and activities are redefined on the basis of values which, differ from values previously taken for granted. New social practices occur very slowly, because the values and their underlying logic take time to become reproduced unquestioningly in routine conduct [36].

There are connections between the institutionalisation stage at the societal level and types of change in organisations [6]. During the stable stage of institutionalisation developmental changes mostly take place. Deinstitutionalisation in society, which starts a period of social transience, calls for transformational changes in organisations. At the same time deinstitutionalization starts.

The research question deals with how values impact attitudes towards changes and how attitudes towards changes influence organisational learning in Turkey.

\section{EMPIRICAL STUDY}

5000 persons from 40 three and four stars hotels in Turkey were included in the study. Hotels were chosen from various destinations on all over Turkey. Approximately 3500 personnel were invited to fill in the survey forms but 1560 of them accepted to participate to the study. 1267 forms remained valid after extracting the forms with unreasonable ratio of missing values.

\section{A. Measures}

All respondents filled out three questionnaires: the questionnaire for measuring work related values, a questionnaire about their attitudes towards changes and a questionnaire about organisational learning. The questions were translated from English into Turkish and retranslated into English. The retranslations were compared to the original English version. In order to make the questions understandable to employees at all levels of the organisations, specific management terms were not used in the questions.

\section{B. Questionnaire for Measuring Work Related Values}

The questionnaire of work related values included 46 items for evaluation of value groups [37]:

Business ideological values or economic values involve the evaluation of the regular analysis of a company's economic activities, the quality of the company's products and services and investment into the company's future at the expense of the present wealth.

Leadership ideological values gauge the staff's personal interest in the quality of the company's products and services, their participation in the development of the company's strategy and readiness and ability for independent decision-making in their sector of activity.

Social values include good relationships among the staff and between superiors and subordinates, lack of conflict within the staff and the lack of conflict between the young and the old.

Speciality-related values relate to an employees' professional education and the acknowledgement of an employee as a specialist in his/her field.

Cultural values involve the established standards of professional behavior in the company, the similarity of professional evaluation criteria for the personnel and "our" feeling in the company.

Personal values comprise the leader's imagination (the speed of thought and openness to new ideas), his or her entrepreneurial spirit and creativity in setting up and solving problems and the manager's skills and life experience.

Values related to the mode of life consist of an assessment 
of the relevance of contemporary office equipment and sufficient computers in the company, and the good condition of the buildings all ensuring the company's activities.

Organizational-legal values involve the staff's understanding of the company's objectives, the existence of professional directions and that they be followed and the management's supervision of staff activities.

And lastly ethical values include honesty as an ethical value, a person's self-respect and its preservation in all situations, and democratic management.

\section{Questionnaire for Measuring Organizational Learning}

To evaluate organizations` learning abilities the author used the measure developed by Alas and Sharifi [38] on the basis of a measure developed by Lähteenmäki, Mattila, and Toivonen [39]. Their measure is based on model, which connects processes of learning and change. To evaluate learning abilities in organizations, Alas and Sharifi [38] grouped indicators of organizational learning by using a cluster analysis in two scales. Both scales consist of eight statements and ranged from 1 to 10 points. Authors let respondents evaluate 21 indicators of organizational learning on a 10 -point scale.

Individual learning means, that individuals learn to be active and develop an open-minded and positive attitude toward risk-taking in order to start to unlearn old knowledge. Two conditions have to be present before people can decide about active participation in decision-making. On the one hand, employees should be aware of and committed to the business objectives and the process of change. And on the other hand, they should also be encouraged to take initiative and be active in relation to their own work [38].

Collective learning means, that staff collectively learn to increase openness in communication. Interconnected collaborative abilities (open communication and willingness to develop) and the ability to use teamwork enable managers to create fluent work processes. Here the ability to learn using a trial and error method by making mistakes and learning from these mistakes plays an important role. Managerial support for personal development and training is also significant [38].

\section{Questionnaire for Measuring Employee Attitudes toward Change}

The author used a questionnaire designed on the basis of statements about satisfaction with leadership, with the job itself and with previous changes [15].

The questionnaire was developed on the basis of items taken from widely used satisfaction and commitment scales. The 15 items concerned a wide range of different topics related to employee attitudes such as - (a) attitudes toward the organization (e.g. "How much are your future plans connected with this organization?"), (b) general attitudes toward the work itself (e.g."How satisfied are you with your present work in this organization?"), (c) attitudes toward managers (e.g."Do you trust the management and think that their decisions are the best for the organization?"), (d) the benefits of the current change (e.g." In your opinion, how necessary are the changes in the organization?"), (e) information about the current change (e.g."Do you have enough information about the reasons, content and objectives of the changes?").

The survey used the Likert scale so the respondents could show their attitudes by choosing answers that range from strongly disagree (1) to strongly agree (5).

The items in the first scale, satisfaction with information (SI), addressing whether employees were satisfied with the information they received, depended on employee involvement in the change process and how much information was given to employees about the current changes and company goals.

The second scale addresses satisfaction with the leadership (SL), and the following issues were most important for employees: how actively does management solve company problems, can management and their decisions be trusted and how well can superiors organize the work of subordinates.

The third scale connected organizational commitment and job satisfaction $(\mathrm{CJ})$ by combining the willingness to continue working for a particular organization and satisfaction with the present job.

The fourth scale deals with questions about the benefits of change (BC) including how necessary the changes were for the organization and how individuals benefit from these changes.

\section{E. Values as Predictors of Attitudes toward Changes and Organizational Learning}

In order to predict individual and organizational learning, a Linear Regression Stepwise method was used. The scales of work related values were taken as independent variables and the scales for organizational learning and attitudes toward changes were taken as dependent variables.

The LRA Stepwise method reveals that $54.6 \%$ of the variability in individual learning and $57.7 \%$ of the variability in collective learning can be explained by reference to the independent variables.

The results in Table I indicate that both scales of organizational learning could be predicted by the leadership ideological values, personal values, speciality-related values and cultural values. Individual learning could also be predicted by organizational-legal values.

The LRA Stepwise method reveals that $31.3 \%$ of the variability in perceived benefit from change and in satisfaction about information about change can be explained by work-related values. These figures for satisfaction with leadership are $34.8 \%$ of and for job satisfaction and commitment to the company $26.2 \%$ of the variability. According to the LRA results in Table I, the cultural values best predict all four scales of attitudes. Leadership ideological values predict three attitude scales: perceived benefit of change, satisfaction with leadership and satisfaction with information about change. Additionally, satisfaction with leadership could also be predicted by personal values and values related to the mode of life. Job satisfaction and commitment to the company could be predicted by personal values and specialty-related values. 
TABLE I: CONNECTIONS BETWEEN WORK-RELATED VALUES, ATTITUDE AND LEARNING

\begin{tabular}{|c|c|c|c|c|c|c|}
\hline & $\begin{array}{l}\text { Individual } \\
\text { learning }\end{array}$ & $\begin{array}{l}\text { Collective } \\
\text { learning }\end{array}$ & $\begin{array}{c}\text { Job } \\
\text { satisfaction }\end{array}$ & $\begin{array}{c}\text { Satisfaction } \\
\text { with leadership }\end{array}$ & $\begin{array}{l}\text { Satisfaction with } \\
\text { information }\end{array}$ & $\begin{array}{c}\text { Benefit from } \\
\text { change }\end{array}$ \\
\hline Adjusted R Square & $54,6 \%$ & $57,7 \%$ & $26,2 \%$ & $34,8 \%$ & $31,3 \%$ & $31,3 \%$ \\
\hline $\begin{array}{l}\text { Values related to the mode of life } \\
\text { Business ideological values }\end{array}$ & \multicolumn{5}{|c|}{ Business ideological values } & \\
\hline \multicolumn{7}{|l|}{ Ethical values } \\
\hline Leadership ideological values & + & + & & + & + & + \\
\hline \multicolumn{7}{|l|}{ Social values } \\
\hline Personal values & + & + & + & + & & \\
\hline Speciality-related values & + & + & + & & + & \\
\hline Organizational-legal values & + & & & & & \\
\hline Cultural values & + & + & + & + & + & + \\
\hline
\end{tabular}

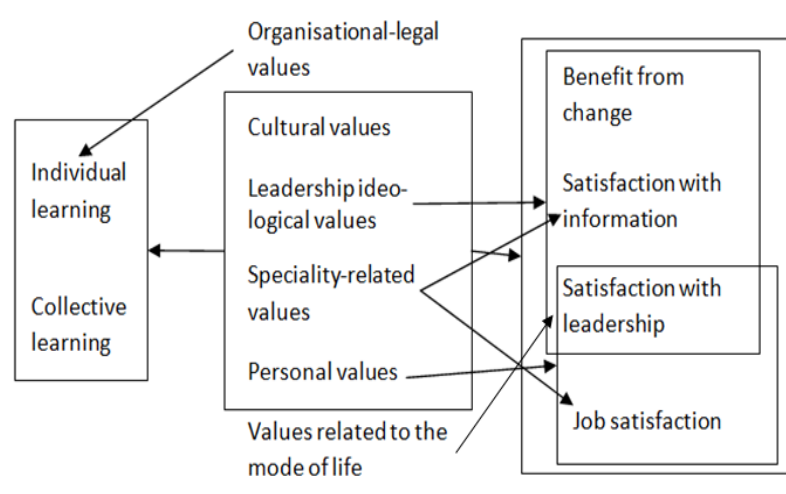

Fig. 1. The model about the impact of work related values on attitudes towards change and on individual and collective learning.

\section{CONCLUSIONS}

The authors examine the influence of work related values on attitudes toward change and organizational learning. Empirical research in Turkish organizations indicates that the Work-related values predict one third from attitudes toward changes and half from organizational learning. The best predictors of attitudes toward change and organizational learning are cultural values and leadership ideological values. Next are speciality-related values and personal values. Business ideological values, social values and ethical values did not predict any scale.

Based research results the authors have developed a model about the impact of work related values on attitudes towards change and on individual and collective learning (Fig. 1).

From the findings of the current study the authors have developed some implications for managers. In order to encourage the individual and collective learning and achieve better attitudes toward changes cultural values could be implemented by establishing standards of professional behavior, the similarity of professional evaluation criteria for the personnel and "our" feeling in the company. Leadership ideological values could be improved via participative leadership, employee involvement, coaching and mentoring. Personal values could improve employees' job satisfaction, if employees have confidence that the managers are able to solve the problems facing the company.

To conclude, this study reveals the importance of the impact of work related values on employees' attitudes towards change and organizational learning in Turkish organizations.

\section{REFERENCES}

[1] B. Burnes, "Reflections: ethics and organizational change - time for a return to Lewinian values," Journal of Change Management, vol. 9, no. 4, pp. 359-381, 2009.

[2] D. A. Buchanan, "Reflections: Good practice, not rocket science understanding failures to change after extreme events," Journal of Change Management, vol. 11, no. 3, pp. 273-288, 2011.

[3] A. Armenakis, and S. Harris, "Reflections: our journey in organizational change and practice," Journal of Change Management, vol. 9, no. 2, pp. 127-142, 2009.

[4] R. A. Heifetz and D. L. Laurie, "The work of leadership," Harvard Business Review, vol. 79, no. 11, pp. 131-140, 2001.

[5] L. Herscovitch and J. P. Meyer, "Commitment to organizational change: Extension of a three-component model," Journal of Applied Psychology, vol. 87, pp. 474-487, 2002.

[6] R. Alas, "Implementation of organizational changes in Estonian companies," Journal of Business Economics and Management, vol. 9, no. 4, pp. 289-297, 2008.

[7] R. Freidland, and R. R. Alford, "Bringing society back in: Symbols, practices, and institutional contradictions," in The New Institutionalism in Organizational Analysis, W. W. Powell, and P. J. DiMaggio, Eds. Chicago: University of Chicago Press, 1991, pp. 232-263.

[8] W. R. Scott, Institutions and Organizations, Sage: Thousand Oaks, CA, 1995.

[9] A. A. Armenakis, S. G. Harris, and K. W. Mossholder, "Creating readiness for organizational change," Human Relations, vol. 46, no. 6, pp. 681- 703, 1993.

[10] D. Silverman, "Formal organization or industrial sociology toward a social action analysis of organizations," Sociology, vol. 2, no. 2, pp. 221-238, May 1968.

[11] C. H. Struckman and F. J. Yammarino, "Organizational change: A categorization scheme and response model with readiness factors," in Research in Organizational Change and Development, R. W. Woodman, and W. A. Pasmore, Eds. Greenwich: JAI Press, 2003, vol. 14, pp. $1-50$.

[12] R. B. Dunham, J. B. Grube, D. G. Gardner, L. L. Cummings, and J. L. Pierce, The Development of an Attitude Toward Change Instrument, Manuscript Submitted for Publication, 1995.

[13] C. Mullan and L. Gorman, "Facilitating adaptation to change: A case study in retraining middle- aged and older workers at aer Lingus," Industrial Gerontology, vol. 15, pp. 20-39, 1972.

[14] J. P. Meyer and N. J. Allen, Commitment in the Workplace: Theory, Research and Applications, Thousand Oaks: Sage Publications, 1997.

[15] R. Alas and M. Vadi, "The impact of organisational culture on attitudes concerning change in post-soviet organisations," Journal for East European Management Studies, vol. 9, no. 1, pp. 20-39, 2004.

[16] R. W. Beatty and D. O. Ulrich, "Re-energizing the mature organization," in Managing Change. Cases and Concepts, T. D. Jick, Ed. Burr Ridge, Il.: Irwin, 1993, pp. 60-74.

[17] D. A. Garvin, "Building a Learning Organization," Harvard Business Review, pp. 78-91, July-August 1993.

[18] P. M. Senge, The Fifth Discipline- The Art and Practice of The Learning Organization, London: Century Business, 1992.

[19] M. Easterby-Smith, M. Crossan, and D. Nicolini, "Organizational learning: debates past present and future," Journal of Management Studies, vol. 37, no. 6, pp. 783-795, 2000.

[20] L. Rosenstiel and S. Koch, "Change in socioeconomic values as a trigger of organisational learning," in Organisational Learning and 
Knowledge, M. Dierkes, A. B. Antal, J. Child, I. Nonaka, Eds. Oxford University Press, 2001, pp. 198-220.

[21] E. W. K. Tsang, "Organisational learning and the learning organisation: A dichotomy between descriptive and prescriptive research," Human Relations, vol. 50, pp. 73-89, 1997.

[22] J. Mahler, "Influences of organizational culture on learning in public agencies," Journal of Public Administration Research \& Theory, vol 7, no. 4, pp. 519-541, 1997.

[23] D. S. Boninger, J. W. Krosnick, and M. K. Berent, "Origins of attitude importance: self-interest, social identification, and value relevance," Journal of Personality and Social Psychology, vol. 68, pp. 61-80, 1995.

[24] T. McEwan, Managing Values and Beliefs in Organisations, Prentice Hall, 2001.

[25] C. Fisher and A. Lovell, Business Ethics and Values, Prentice Hall, 2003.

[26] M. Rokeach, The Nature of Human Values, New York: The Free Press, 1973.

[27] A. Gini, "Moral leadership and business ethics," in Ethics, the heart of leadership, J. B. Ciulla, Ed. Praeger, 2004, pp. 25-43.

[28] N. J. Adler, Internetional dimensions of organizational behavior, 4th ed. Boston, MA: Kn Publishing (Original work published 1986), 2002.

[29] R. Lebow and W. L. Simon, Lasting change: The shared values process that makes company great, John Wiley \& Sons, Inc, 1997.

[30] W. R. Nord, A. P. Brief, J. M. Atieh, and E. M. Doherty, "Work values and the conduct of organizational behavior," Research in Organizational Behavior, vol. 10, pp. 1-42, 1988.

[31] A. Altıparmak, "Türkiye'de Cumhuriyetin İlkYıllarında Müteşebbis Sınıfın Gelișimi," Ballkesir Üniversitesi Sosyal Bilimler Enstitüsü Dergisi, vol. 1, no. 1, pp. 65-80, January 1998.

[32] H. Kabasakal and M. Bodur, "Arabic cluster: A bridge between East and West," Journal of World Business, vol. 37, pp. 40-54, 2002.

[33] S. Ülgener, Iktisadi İnhitat Tarihimizin Ahlak ve Zihniyet Meseleleri, İsmail Akgün, 1951.

[34] Akyıldız and Hüseyin ve Ömer Eroğlu, "The economic policies pursued up to Now from the foundation of the Turkish Republic," Süleymen Demirel Üniversitesi, Íktisadi ve İdari Bilimler Fakültesi, vol. 9, no. 1, pp. 43- 62, 2004.

[35] S.. Pamuk, "Economic growth in the world and Turkey (1820- 2005)," Uluslararası Ekonomi ve Dış Ticaret Politikaları, vol. 1, no 2, pp. 3-26, 2007.

[36] E. Clark and A. Soulsby, Organisational Change in Post-Communist Europe: Management and transformation in the Czech Republic, Routledge, 1999.

[37] R. Alas, J. Ennulo, and L. Türnpuu, "Managerial values in the institutional context," Journal of Business Ethics, vol. 65, no. 3, pp. $269-278,2006$
[38] R. Alas and S. Sharifi, "Organizational learning and resistance to change in Estonian companies," Human Resource Development International, vol. 5, no. 3, pp. 313-331, 2002.

[39] S. Lähteenmäki, M. Mattila, and J. Toivonen, "Being critical on organizational learning research - towards developing a measure," in HRM and the Learning Organization. Publications of the Turku School of Economics and Business Administration, S. Lähteenmäki, L. Holden, I. Roberts, Eds. pp. 17-49, 1999.

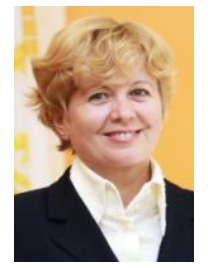

Ruth Alas currently holds the positions of vice-rector for Research and Head of The Department of Management at Estonian Business School (EBS). Prior to joining EBS, she worked as a consultant. Her field of research involves change and crisis management, focusing on employee attitudes, learning abilities, organisational culture, innovation climate, leadership, values, ethics and corporate social responsibility. She has supervised doctoral theses and has acted as external examiner for doctoral theses on these topics. Furthermore, she received the CEEMAN Champions' Award 2011 for Academic Research on the topic "How to prevent Crisis by means of Organisational Change Management". (CEEMAN is an international management development association in central and eastern Europe).

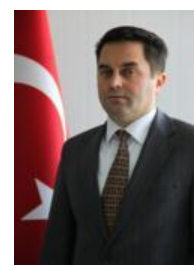

Halil Demirer has work experience in the hotel industry in the first years of his career. He got Ph.D. in Business Management and Organization, from Istanbul University in 1998. From 2007 he works for School of İskenderun Civil Aviation Mustafa Kemal University. He has been rewarded with The Best Paper Award in "European Applied Business Research Conference" 2009 Prag with the paper presented "European Passengers' Satisfaction and Fairness Perceptions About Turkish Airports". He is a member of EURAM.

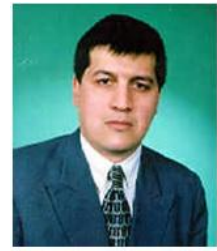

Necdet Bilgin worked for School of Tourism Management Erciyes University from 1998-2007. Currently he works for Faculty of Economics and Administrative Sciences of Celal Bayar University Manisa. He has co-authored with Mazlum Celik and Ömer Turunç "Moderating Role of the Ethic", Journal of Applied Sciences, vol.12, no. 6, pp. 554-552, 2012. 